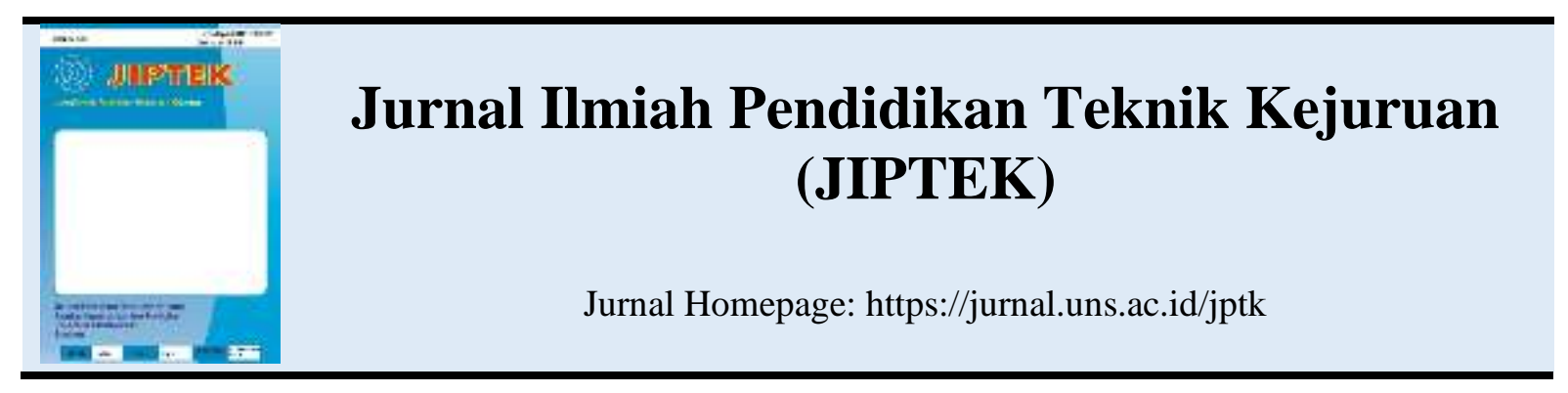

\title{
STUDI NUMERIKAL PERFORMANSI TURBIN ANGIN SAVONIUS DI PESISIR PANTAI KABUPATEN DEMAK
}

\author{
Muhammad Emir Purdiatama, Herman Saputro, Danar Susilo Wijayanto \\ Program Studi Pendidikan Teknik Mesin, Universitas Sebelas Maret \\ E-mail: epurdiatama@student.uns.ac.id
}

\begin{abstract}
Abstrak
Sumber energi angin dapat dikonversi menjadi energi listrik menggunakan turbin angin Savonius tipe S. Turbin angin Savonius akan diterapkan di Pantai Pesisir Kabupaten Demak karena memiliki kecepatan angin yang memadai. Studi numerik menggunakan perangkat lunak ANSYS R. 15 dilakukan untuk menentukan daya potensial yang dihasilkan oleh turbin menggunakan satu sirip dan tanpa menggunakan sirip. Desain turbin dibuat menggunakan aplikasi SolidWorks kemudian diimpor ke ANSYS R.15. Model mesh yang digunakan adalah model segitiga. Dalam menu kondisi batas, variasi kecepatan angin di pantai Kabupaten Demak adalah input saat pengaturan dengan literasi / waktu 100 dan kecepatan sudut 6,59. Sehingga koefisien daya (Cp) dari setiap variasi kecepatan angin diketahui dan hasilnya digunakan untuk menemukan kekuatan pada setiap variasi kecepatan angin. Hasil penelitian menunjukkan bahwa nilai numerik turbin satu sirip lebih besar daripada tanpa menggunakan sirip. Jumlah kecepatan angin berbanding lurus dengan daya yang dihasilkan oleh turbin. Turbin angin Savonius cocok sebagai pembangkit listrik jika generator mampu memaksimalkan daya turbin menjadi tenaga listrik.
\end{abstract}

Kata kunci: Turbin Savonius, ANSYS, Power Coeffecient ( $C p$ ).

\section{Abstract}

Wind energy sources can be converted into electrical energy using Savonius type $S$ wind turbines. Savonius wind turbines will be implemented in the Coastal Coast of Demak Regency because they have adequate wind speed. Numerical studies using ANSYS R. 15 software were carried out to determine the potential power generated by the turbine using one fin and without using fins. The turbine design is made using the SolidWorks application then imported into ANSYS R.15. The mesh model used is the triangle model. In the boundary conditions menu, variations in wind speed on the coast of the Demak Regency are input when setting with literacy/time of 100 and angular velocity of 6.59. So the power coefficient $(\mathrm{CP})$ of each variation of wind speed is known and the results are used to find the strength at each variation of wind speed. The results showed that the numerical value of a single turbine fin is greater than without using fins. The amount of wind speed is directly proportional to the power produced by the turbine. Savonius wind turbines are suitable as a power plant if the generator is able to maximize turbine power into electric power.

Keywords: Savonius Turbine;ANSYS;Power Coeffecient (Cp).

\section{Pendahuluan}

Kebutuhan energi semakin lama semakin bertambah sedangkan ketersediaannya semakin lama semakin berkurang, terutama energi sumber daya minyak bumi. Pemerintah maupun pihak swasta selalu membuat inovasi dan berlomba semaksimal mungkin menggunakan energi baru terbarukan untuk 
menjaga ketersediaan energi negaranya. Energi baru terbarukan merupakan energi yang tidak akan habis dan dapat diperbarui. Selain itu energi baru terbarukan relatif mudah didapat, gratis, dan minim limbah.

Sumber daya angin di Indonesia berpotensi menghasilkan daya energi yang dapat dimanfaatkan. Salah satu tempat yang memiliki potensi angin cukup baik yaitu di pesisir pantai Kabupaten Demak. Dari data praeksperimen yang telah dilakukan, menunjukkan kecepatan angin berkisar $1,0 \mathrm{~s} / \mathrm{d}$ $4,5 \mathrm{~m} / \mathrm{s}$ serta pada saat siang dan sore hari ratarata kecepatan angin 2,7 $\mathrm{m} / \mathrm{s}$. Rata-rata kecepatan angin yang mencapai $2,7 \mathrm{~m} / \mathrm{s}$ harusnya bisa dimanfaatkan sebagai sumber energi angin, namun belum ada yang memanfaatkannya secara maksimal. Oleh karena itu pemanfaatan sumber daya angin untuk pembangkit energi listrik bisa dilakukan menggunakan turbin Savonius. Turbin angin Savonius merupakan model turbin yang digunakan untuk kecepatan angin rendah (Wenehenubun, Saputra, \& Sutanto, 2015). Kincir angin Savonius merupakan alat untuk mengubah energi kecepatan angin menjadi energi gerak dengan poros vertikal yang mudah dibuat, desain sederhana, dapat bekerja pada kecepatan angin dan putaran yang rendah (Sugiharto, dkk, 2015). Keuntungan utama dari turbin Savonius adalah desainnya yang sederhana dan kemampuannya untuk beroperasi di berbagai arah angin (Kumar, 2018).

Selama ini beberapa penelitian menggunakan metode eksperimen dengan membuat turbin angin Savonius untuk mengetahui performansinya. Namun secara segi ekonomis metode penelitian tersebut memerlukan biaya untuk pengadaan alat. Salah satu solusi untuk mengatasinya yaitu dengan cara simulasi turbin angin menggunakan metode Computational of Fluid Dynamic (CFD). Simulasi menggunakan CFD dapat menunjukan hasil uji performansi desain turbin melalui proses komputasi. Hal ini juga berguna untuk mengetahui performansi turbin yang akan diaplikasikan tanpa melakukan eksperimen terlebih dahulu, sehingga menghemat biaya dan waktu. Simulasi ini juga dapat menunjukkan hasil uji berapa besar daya yang dihasilkan oleh turbin dari variabel kecepatan angin. Melalui penelitian ini diharapkan diperoleh tambahan pengetahuan tentang performansi yang dihasilkan.

\section{Metode Penelitian}

Metode penelitian yang digunakan pada penelitian ini adalah metode Computational Fluid Dynamic (CFD) dengan menggunakan software ANSYS R.15. Hasil dari komputasi ini nantinya akan menganalisis perbandingan turbin menggunakan satu fin dengan tanpa fin. Penilitian ini juga untuk mengetahui daya yang dihasilkan oleh turbin angin Savonius di pesisir pantai Kabupaten Demak.

\section{Hasil Penelitian dan Pembahasan}

Pada peneletian ini data yang diperoleh adalah frekuensi kecepatan angin $(\mathrm{m} / \mathrm{s})$ di Pesisir Pantai Kabupaten Demak. Data penelitian diambil selama 3 hari pada kondisi cuaca berawan. Pengambilan data dilakukan dengan mengambil 12 nilai kecepatan angin dalam interval $0,1 \mathrm{~m} / \mathrm{s}$ setiap menitnya. Cara pengambilan data tersebut di lakukan untuk mengurangi kemungkinan terjadinya data yang bias karena perubahan kecepatan angin yang signifikan. Hasil pengukuran kecepatan angin dalam rentang waktu 3 jam per hari selama 3 hari berturut-turut diperoleh 4596 data. Lima frekuensi kecepatan angin terbanyak akan dijadikan variabel simulasi menggunakan metode CFD (Computational Fluid Dynamic) dengan aplikasi ANSYS R.15. frekuensi kecapatan angin terbanyak ditunjukkan pada gambar berikut :

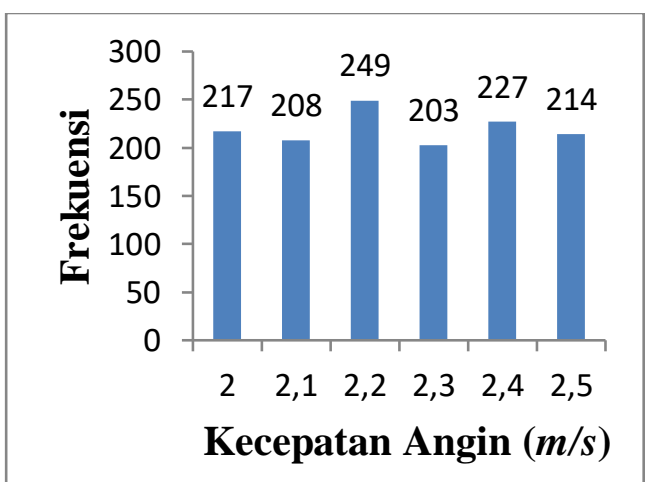

Gambar 1 Frekuensi Kecepatan Angin

Tertinggi dari Semua Frekuensi Kecepatan Angin

Gambar tersebut menunjukkan kecepatan angin $2 \mathrm{~m} / \mathrm{s}, 2,1 \mathrm{~m} / \mathrm{s}, 2,2 \mathrm{~m} / \mathrm{s}, 2,4 \mathrm{~m} / \mathrm{s}$, $2,5 \mathrm{~m} / \mathrm{s}$ merupakan kecepatan angin dengan frekuensi tertinggi.

Desain awal 3D turbin Savonius dibuat menggunakan software SolidWorks. Selanjutnya desain 3D diekspor ke dalam 
software ANSYS R. 15 untuk membuat boundary condition. Turbin dan boundary condition yang telah dibuat kemudian mengalami proses meshing. Proses meshing bertujuan untuk memecah model dan membagi solution domain menjadi bagian kecil yang disebut cell. Meshing disetting sedemikian rupa supaya hasil permodelan dapat memperlihatkan hasil yang teliti dan mendetail. Setelah proses meshing selesai masuk ke proses boundary condition dengan menggunakan jenis turbulensi Standard $k-\varepsilon$. Turbulensi Standard $k-\varepsilon$ digunakan karena simulasi yang digunakan keadaan transien. Setelah itu dalam proses boundary condition juga dimasukkan beberapa variabel kecepatan angin yang akan diuji dan dicari dayanya. Setelah proses simulasi dilakukan, maka akan diketahui hasil koefisien daya $(\mathrm{Cp})$ pada setiap kecepatan angin. Setelah diketahui masing-masing kofisien daya $(\mathrm{Cp})$ dari setiap variabel kecepatan angin, kemudian dimasukkan pada persamaan rumus untuk mengetahui daya turbin. Proses meshing yang digunakan pada permodelan turbin angin Savonius tipe $\mathrm{S}$ ini menggunakan mesh jenis triangular. Pada domain permodelan diaplikasikan sizing sebagai berikut:

Tabel 1 Pengaturan Sizing

\begin{tabular}{l|l}
\hline \multicolumn{2}{c}{ Sizing } \\
\hline Relevance center & Fine \\
Smoothing & Medium \\
Transition & Slow \\
Span angle center & Fine \\
\hline
\end{tabular}

Lima variasi kecepatan angin dengan frekuensi terbanyak disimulasikan menggunakan aplikasi ANSYS R.15. Variasi kecepatan angin disimulasikan pada desain Turbin Savonius menggunakan satu fin dan tanpa menggunakan fin. Setelah setiap variasi kecepatan angin disimulasikan, maka koefisien daya $(\mathrm{Cp})$ setiap kecepatan angin diketahui. Nilai koefisien daya (Cp) setiap variasi kecepatan angin turbin Savonius tanpa fin ditunjukkan pada tabel berikut:

Tabel 2 Nilai Cp Setiap Kecepatan Angin Tanpa Fin

\begin{tabular}{|c|c|}
\hline $\begin{array}{l}\text { Nilai Kecepatan } \\
\text { Angin }\end{array}$ & $\begin{array}{l}\text { Koefesien Daya } \\
\text { (Cp) }\end{array}$ \\
\hline $2 \mathrm{~m} / \mathrm{s}$ & 0,20 \\
\hline $2,1 \mathrm{~m} / \mathrm{s}$ & 0,22 \\
\hline $2,2 \mathrm{~m} / \mathrm{s}$ & 0,24 \\
\hline $2,4 \mathrm{~m} / \mathrm{s}$ & 0,27 \\
\hline $2,5 \mathrm{~m} / \mathrm{s}$ & 0,29 \\
\hline
\end{tabular}

kecepatan angin turbin Savonius menggunakan satu fin ditunjukkan pada tabel berikut:

Tabel 3 Nilai Cp Setiap Kecepatan Angin dengan Satu Fin

\begin{tabular}{cc}
\hline $\begin{array}{c}\text { Nilai Kecepatan } \\
\text { Angin }\end{array}$ & $\begin{array}{c}\text { Koefesien Daya } \\
\text { (Cp) }\end{array}$ \\
& \\
\hline $2 \mathrm{~m} / \mathrm{s}$ & 0,27 \\
$2,1 \mathrm{~m} / \mathrm{s}$ & 0,30 \\
$2,2 \mathrm{~m} / \mathrm{s}$ & 0,33 \\
$2,4 \mathrm{~m} / \mathrm{s}$ & 0,36 \\
$2,5 \mathrm{~m} / \mathrm{s}$ & 0,39 \\
\hline
\end{tabular}

Data pada tabel tersebut menunjukkan bahwa nilai $\mathrm{Cp}$ bertambah 0,3 setiap pertambahan kecepatan angin $0,1 \mathrm{~m} / \mathrm{s}$. Perbandingan besarnya koefisien daya $(\mathrm{Cp})$ yang dihasilkan oleh simulasi ANSYS R.15 turbin angin Savonius satu fin dengan tanpa fin ditunjukkan pada grafik berikut:

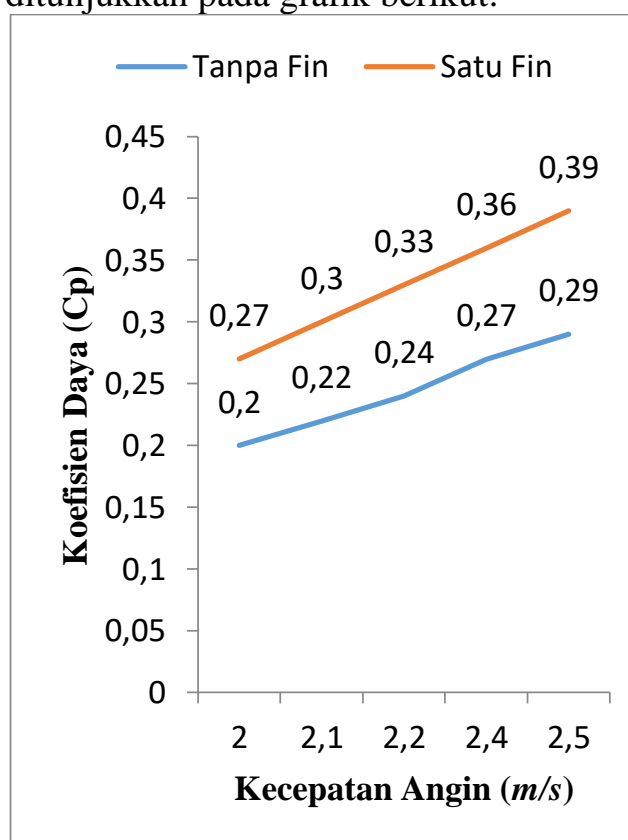

Gambar 2 Grafik Perbandingan Satu Fin dengan tanpa Fin

Nilai koefisien daya (Cp) turbin Savonius menggunakan satu fin lebih besar dibanding tanpa menggunakan fin. Nilai Koefisien daya (Cp) turbin angin Savonius 
menggunakan satu fin dengan tanpa fin memiliki selisih yang kecil.

Hasil koefisien daya (Cp) yang diperoleh dari simulasi menggunakan software ANSYS R.15, akan dibandingkan dengan penelitian uji eksperimental turbin angin Savonius (Pamungkas, 2017). Nilai koefisien daya $(\mathrm{Cp})$ untuk turbin angin Savonius tanpa menggunakan fin dan menggunakan satu fin menurut (Pamungkas, 2017) ditunjukkan pada tabel berikut:

Tabel 4 Nilai Koefisien Daya Turbin Angin Savonius Uji Eksperimental

\begin{tabular}{ccc}
\hline $\begin{array}{c}\text { Kecepatan } \\
\text { Angin } \\
(\mathrm{m} / \mathrm{s})\end{array}$ & $\begin{array}{c}\text { Koefisien } \\
\text { Daya (Cp) } \\
\text { Turbin Angin } \\
\text { Savonius } \\
\text { tanpa } \\
\text { menggunakan } \\
\text { Fin }\end{array}$ & $\begin{array}{c}\text { Koefisien } \\
\text { Daya (Cp) } \\
\text { Turbin Angin } \\
\text { Savonius } \\
\text { menggunakan } \\
\text { Satu Fin }\end{array}$ \\
\hline $2 \mathrm{~m} / \mathrm{s}$ & 0 & 0,42 \\
$2,1 \mathrm{~m} / \mathrm{s}$ & 0 & 0,45 \\
$2,2 \mathrm{~m} / \mathrm{s}$ & 0,38 & 0,49 \\
$2,4 \mathrm{~m} / \mathrm{s}$ & 0,42 & 0,58 \\
$2,5 \mathrm{~m} / \mathrm{s}$ & 0,46 & 0,66
\end{tabular}

Perbandingan grafik nilai koefisien daya (Cp) hasil simulasi dengan uji eksperimental turbin angin Savonius tanpa fin ditunjukkan pada grafik berikut:

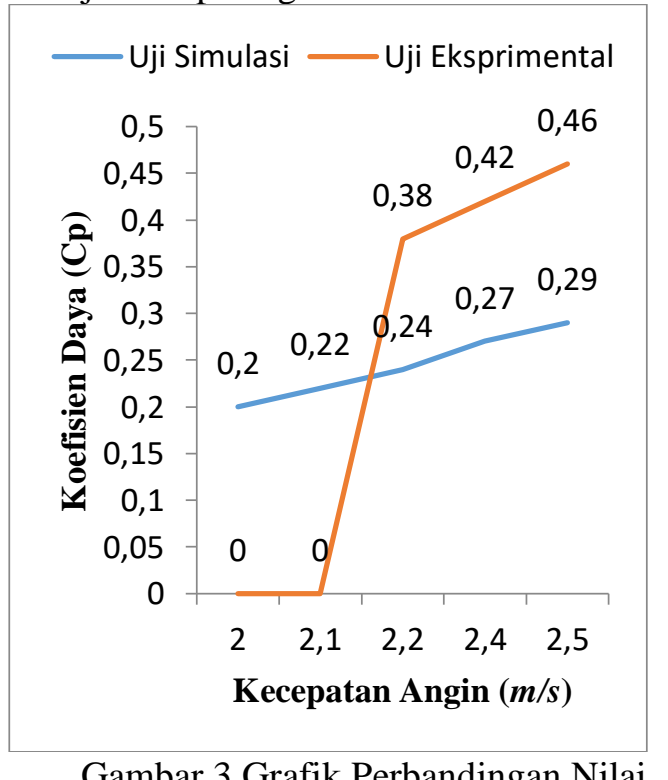

Gambar 3 Grafik Perbandingan Nilai

Koefisien Daya Hasil Simulasi dengan Uji Eksperimental Turbin Savonius Tanpa Fin

Grafik tersebut menunjukkan selisih koefisien daya uji eksperimental dengan simulasi tidak cukup besar. Nilai koefisien daya (Cp) uji eksperimental pada kecepatan angin 2 $\mathrm{m} / \mathrm{s}$ dan $2,1 \mathrm{~m} / \mathrm{s}$ bernilai 0 karena turbin mulai berputar pada kecepatan 2,2 $\mathrm{m} / \mathrm{s}$. Nilai koefisien daya $(\mathrm{Cp})$ uji eksperimental lebih besar karena luas penampang turbin yang digunakan pada uji eksperimental lebih besar.

Perbandingan grafik nilai koefisien daya (Cp) hasil simulasi dengan uji eksperimental turbin angin Savonius menggunakan satu fin ditunjukkan pada grafik berikut :

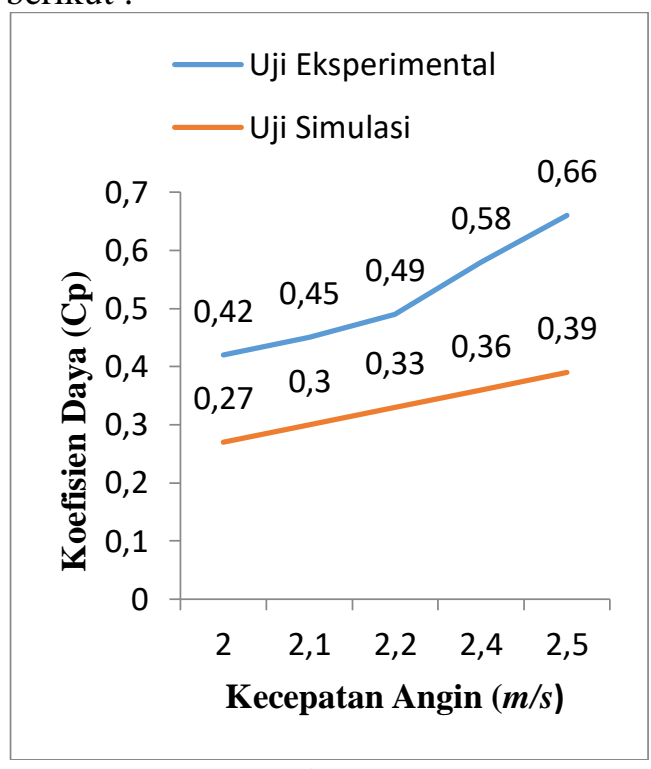

Gambar 4 Grafik Perbandingan Nilai

Koefisien Daya Hasil Simulasi dengan Uji

Eksperimental Turbin Savonius menggunakan satu Fin

Grafik tersebut menunjukkan hasil uji eksperimental dengan uji numerikal sesuai sebab selisih Cp (koefisien daya) yang kecil. Nilai koefisien daya (Cp) uji eksperimental lebih besar karena luas penampang turbin yang digunakan pada uji eksperimental lebih besar.

Setelah diketahui nilai $\mathrm{Cp}$, maka untuk mengetahui daya turbin yang dihasilkan dapat digunakan rumus persamaan:

$$
\begin{aligned}
& \mathrm{P}=\mathrm{Cp} 1 / 2 \rho \mathrm{Av}^{3} \\
& \text { Dimana : } \\
& \mathrm{P}=\text { Daya }(\text { Watt }) \\
& \mathrm{Cp}=\text { Keofesien daya } \\
& \rho=\text { Kerapatan udara }\left(1,2 \mathrm{Kg} / \mathrm{m}^{3}\right) \\
& \mathrm{A}=\text { Luas Penampang }\left(\mathrm{m}^{2}\right) \\
& \mathrm{V}=\text { Kecepatan angin }(\mathrm{m} / \mathrm{s}) \\
& \text { Luas penampang diketahui dari data }
\end{aligned}
$$
spesifikasi geometri turbin. Diketahui Geometri turbin Savonius :

Diameter Blade/Sudu (D) $\quad=700$

$m m$

$1400 \mathrm{~mm}$

Tinggi blade/sudu ( $\mathrm{t}$ ) =

Maka luas penampang sudu:

$\mathrm{A}=\mathrm{D} \times \mathrm{t}$ 


$$
\begin{aligned}
& \mathrm{A}=7 m \times 14 m \\
& \mathrm{~A}=98 m^{2}
\end{aligned}
$$

Setelah diketahui nilai penampang sudu dan nilai koefisien daya (Cp) maka daya dapat diketahui melalui perhitungan menggunakan rumus persamaan. Daya turbin hasil uji simulasi setiap kecepatan angin melalui perhitungan menggunakan rumus persamaan dapat diketahui pada grafik berikut:

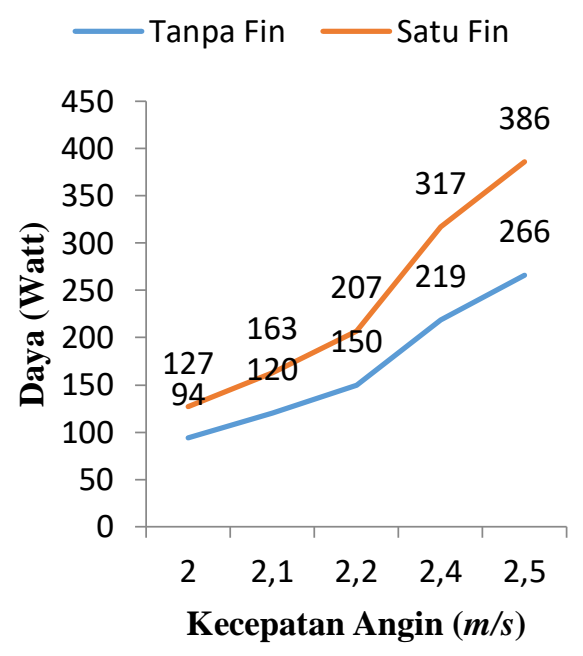

Gambar 5 Grafik Daya terhadap Kecepatan Angin

Grafik tersebut menunjukkan besarnya kecepatan angin berbanding lurus dengan daya yang dihasilkan. Daya terendah diketahui dari turbin tanpa fin sebesar 94 Watt. Daya tertinggi diketahui dari turbin dengan satu fin sebesar 386 Watt. Daya yang dihasilkan turbin angin Savonius menggunakan satu fin lebih besar dibanding daya yang dihasilkan turbin Savonius tanpa fin.

Daya turbin dari hasil simulasi menunjukkan turbin angin Savonius menghasilkan daya yang besar, namun pada uji eksperimental daya listrik yang dihasilkan tidak begitu besar. Data hubungan kecepatan angin terhadap daya yang dihasilkan turbin Savonius uji eksperimental menurut (Pamungkas, 2017) yaitu :

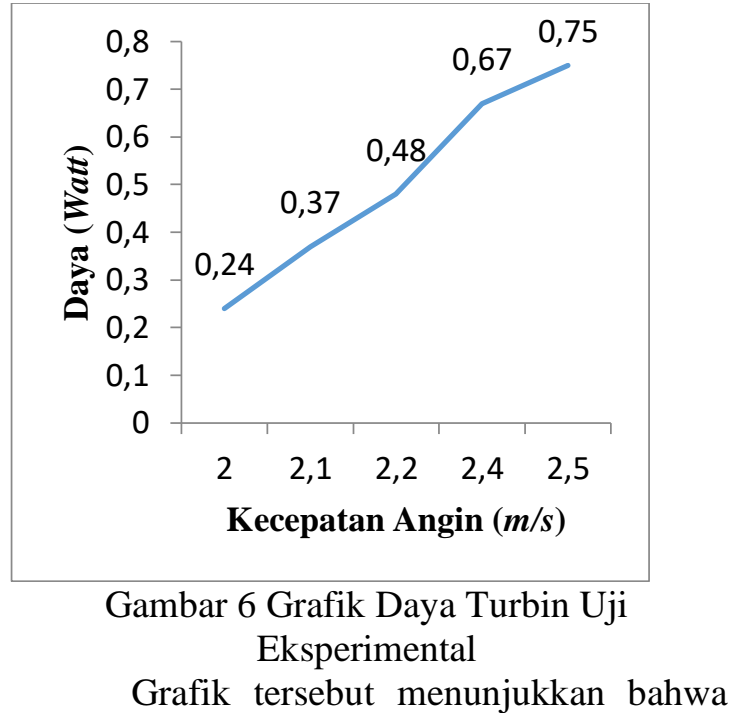

daya listrik yang dihasilkan oleh turbin Savonius kecil. Pada kecepatan angin $2 \mathrm{~m} / \mathrm{s}$ menghasilkan daya listrik terendah yaitu 0,24 Watt sedangkan pada kecepatan angin 2,5 m/s menunjukkan daya listrik tertinggi yaitu 0,75 Watt.

Pada penelitian numerikal ini, energi angin sepenuhnya diekstrak untuk meghasilkan daya menggunakan metode CFD (Computational Fluid Dynamid) dengan permodelan turbulensi Standard $k-\varepsilon$. Penelitian numerikal ini menggunakan metode CFD (Computational Fluid Dynamic) sehingga tidak ada penggunaan generator. Tidak adanya penggunaan generator pada uji numerikal menjadikan hambatan yang dihasilkan generator juga tidak ada.

Besarnya selisih daya uji numerikal dengan uji eksperimental disebabkan oleh generator pada uji eksperimental yang belum maksimal mengubah daya turbin menjadi daya listrik. Faktor lain yang menghambat seperti kelembaban udara dan suhu juga tidak mempengaruhi uji numerikal. Hal itu menunjukkan bahwa turbin angin Savonius cocok sebagai pembangkit listrik jika generator mampu memaksimalkan daya turbin menjadi daya listrik. Turbin angin Savonius juga dapat dimanfaatkan putarannya sebab memiliki daya turbin yang besar.

\section{Simpulan dan Saran}

Simpulan

Kesimpulan dari penelitian ini adalah

1. Hasil simulasi dengan menggunakan CFD (Computational Fluid Dynamic) satu fin 
lebih besar dibandingkan dengan tanpa mengguanakan fin.

2. Nilai koefisien daya $(\mathrm{Cp})$ uji numerikal turbin angin Savonius dengan menggunakan satu fin naik 0,3 setiap kenaikan $0,1 \mathrm{~m} / \mathrm{s}$.

3. Hasil uji eksperimental dengan uji numerikal sesuai sebab selisih koefisien daya (Cp) yang kecil. Nilai koefisien daya (Cp) uji eksperimental lebih besar karena luas penampang turbin yang digunakan pada uji eksperimental lebih besar.

4. Besarnya daya pada uji numerikal berbanding lurus dengan besarnya kecepatan angin sesuai dengan penelitian eksperimental yang menunjukkan hal serupa. Pada uji eksperimental daya terendah ditunjukkan pada kecepatan angin $2 \mathrm{~m} / \mathrm{s}$ yaitu 0,24 Watt sedangkan daya tertinggi ditunjukkan pada kecepatan angin $2,4 \mathrm{~m} / \mathrm{s}$ yaitu 0,75 Watt. Pada uji numerikal daya terendah diketahui dari turbin tanpa fin sebesar 94 Watt pada kecepatan angin $2 \mathrm{~m} / \mathrm{s}$. Daya tertinggi diketahui dari turbin dengan satu fin sebesar 386 Watt pada kecepatan angin 2,5 $\mathrm{m} / \mathrm{s}$.

5. Turbin angin Savonius cocok sebagai pembangkit listrik jika generator mampu memaksimalkan daya turbin menjadi daya listrik. Turbin angin Savonius juga dapat dimanfaatkan putarannya sebab memiliki daya turbin yang besar.

Saran

1. Peneliti selanjutnya dapat mengembangkan simulasi turbin angin savonius menggunakan metode CFD (Computational Fluid Dynamic) ini untuk parameter desain atau kondisi angin di daerah lain.

2. Peneliti selanjutnya dapat mengembangkan lagi permodelan atau simulasi turbin angin Savonius ini seperti penambahan jumlah fin pada turbin, sehingga dapat memperoleh daya yang lebih maksimal.

3. Peneliti selanjutnya dapat menambahkan faktor lain seperti kecepatan angin seperti kelembaban udara, suhu, dan lain-lain sehingga hasil daya yang diperoleh lebih akurat.
4. Peneliti uji eksperimental supaya menggunakan generator yang berkualitas sehingga daya listrik yang dihasilkan turbin Savonius bisa optimal.

\section{Daftar Pustaka}

Al-Shemmeri. (2010). Wind Turbines. Frederiksberg, Denmark : Ventus Publishing ApS.

Anggara, B. (2018). Studi Numerikal Turbin Angin Savonius Tipe $\mathrm{S}$ dengan Penambahan Fin pada Blade Menggunakan Metode Computational Fluid Dynamic (CFD). Skripsi. Surakarta : Universitas Sebelas Maret.

Kumar R, S., Premkumar T, M., Sivamani, S., Hariram V. (2018). Numerical Analysis of Different Blade Shapes of a Savonius Style Vertical Axis Wind Turbine. International Journal of Renewable Energy Research.

Pamungkas, S. F. (2017). Performansi Turbin Angin Savonius Tipe S dengan Variasi Penambahan Fin pada Sudu dan Kecepatan Angin. Skripsi. Surakarta : Universitas Sebelas maret.

Pamungkas, S. F., Wijayanto, D. S., Saputro, H. (2017). Pengaruh Variasai Penambahan Fin terhadap Cut in Speed Turbin Angin Savonius Tipe S.VANOS Journal of Mechanical Engineering Education.

Pamungkas, S. F., Wijayanto, D. S., Saputro, H., Widiastuti, I. (2018). Performance 'S' Type Savonius Wind Turbine with Variation of Fin Addition on Blade. Jurnal Penelitian. Annual Applied Science and Engineering Conference 2017.

Prasetyo, Y. B. (2017). Simulasi Numerik Pengaruh Perbedaan Sudut Kemiringan Bilah pada Turbin Angin Sumbu Vertikal Jenis Helical Terhadap Kinerja Turbin Angin. Jurnal Penelitian.

Riza, A., Darmawan, S. (2013). Pengaruh Variabel Kecepatan Angin Terhadap Turbin Angin Horizontal Aksial Dengan Profil Airfoil Blade Sesuai Standar Naca 2418. Seminar Nasional Mesin dan Industri. Jakarta : Jurusan Teknik Mesin 
Fakultas Teknik Universitas Tarumanegara.

Sugiharto, B., Widhiyanuwirawan, D., Wahyudi, S., \& Soeparman, S. (2015). Simulasi Peningkatan Kinerja Kincir Angin Savonius dengan Empat Plat Pengarah. Jurnal Penelitian, 53 - 58.

Tania, R., Florin, R. L., Adriana, I.D., Roxana, M., Ancuta, A., Florin, D. (2018).
Experimental Investigation on the Influence of Overleap Ratio on Savonius Turbines Performance. International Journal of Renewable Energy Research.

Wenehenubun, F., Saputra, A., \& Sutanto, H. (2015). An experimental study on the performance of Savonius wind turbines related with the number of blades. Energy Procedia. Amsterdam, Netherlands : Elsevier Ltd. 